Instructions for authors, subscriptions and further details:

\title{
http://rimcis.hipatiapress.com
}

\section{The Essence of Education in Disruptive COVID-19 Crisis: Capturing the Lived Experience of College Students in the Philippines}

Michael B. Cahapay ${ }^{1}$

1) Mindanao State University-General Santos City, Philippines

Date of publication: Online First 29 November 2021; Issue published 30 November 2021

Edition period: November 2021 - March 2022

To cite this article: Cahapay, M.B. (2021). The Essence of Education in Disruptive COVID-19 Crisis: Capturing the Lived Experience of College Students in the Philippines. International and Multidisciplinary Journal of Social Sciences, 10(3), 22-39. doi: 10.17583/rimcis.7759

To link this article: http://doi.org/10.17583/rimcis.7759 
The terms and conditions of use are related to the Open Journal System and to Creative Commons Attribution License(CC-BY).

\section{The Essence of Education in Disruptive COVID-19 Crisis: Capturing the Lived Experience of College Students in the Philippines}

Michael B. Cahapay

Mindanao State University-General

Santos City

Abstract

Asserting a responsive, appropriate, and relevant education has historically always been a problem for most learners from marginalized groups. This extant inequality has been magnified in the present novel crisis. Thus, drawing from the lived experience of college students belonging to the marginalized group of indigenous peoples, this research described the essence of education in the context of the current COVID-19 crisis. Following the phenomenological approach based upon the hermeneutic rule of Dahlberg et al. (2008), the researcher interviewed 10 Filipino college students who identify themselves as indigenous peoples. Four themes emerged: 1.) It surprised me: Education has a changed ecology; 2.) It overwhelmed me: Education is fraught with divides; 3.) It motivated me: Education is a driver of aspiration beyond crisis; and 4.) It taught me: Education has unintended positive outcomes. These themes form the structure of the essence of education amid the COVID-19 crisis from the perspectives of college students belonging to the group of indigenous peoples. This research underlines the practical significance of analyzing the state of the students amid a virulent crisis. Given the extant inequality and considering the anticipated educational recovery phase, measures should be planned towards the attainment of responsive, appropriate, and relevant education.

Keywords: education, lived experience, indigenous people, COVID-19, Philippines 


\title{
La Esencia de la Educación en la Disruptiva Crisis de COVID-19: Capturando la Experiencia Vivida de Estudiantes Universitarios en Filipinas
}

\author{
Michael B. Cahapay \\ Mindanao State University-General \\ Santos City
}

\section{Resumen}

Asegurar una educación receptiva, apropiada y relevante históricamente siempre ha sido un problema para la mayoría de los estudiantes de grupos marginados. Esta desigualdad existente se ha magnificado en la nueva crisis actual. Así, a partir de la experiencia vivida por estudiantes universitarios pertenecientes al grupo marginado de los pueblos indígenas, esta investigación describió la esencia de la educación en el contexto de la actual crisis del COVID-19. Siguiendo el enfoque fenomenológico basado en la regla hermenéutica de Dahlberg et al. (2008), el investigador entrevistó a 10 estudiantes universitarios filipinos que se identifican como pueblos indígenas. Surgieron cuatro temas: 1.) Me sorprendió: la educación ha cambiado la ecología; 2.) Me abrumaba: la educación está plagada de divisiones; 3.) Me motivó: la educación es un motor de aspiración más allá de la crisis; y 4.) Me enseñó: La educación tiene resultados positivos no deseados. Estos temas forman la estructura de la esencia de la educación en medio de la crisis del COVID-19 desde la perspectiva de los estudiantes universitarios pertenecientes al grupo de los pueblos indígenas. Esta investigación subraya la importancia práctica de analizar el estado de los estudiantes en medio de una crisis virulenta. Dada la desigualdad existente y considerando la fase de recuperación educativa anticipada, se deben planificar medidas para lograr una educación receptiva, apropiada y relevante.

Palabras clave: educación, experiencias vividas, pueblos indígenas, COVID19, Filipinas 


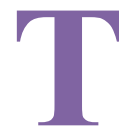

he COVID-19 is a highly communicable human coronavirus caused by severe acute respiratory syndrome coronavirus (Zhou et al., 2020). was declared a pandemic in March 2020. It has since stretched across continents, countries, and territories, disrupting social, political, and economic systems. As of August 30, 2021, worldwide statistics indicate that there have been 214,468,601 confirmed cases, including 4,470,969 deaths (World Health Organization, 2021).

The crisis caused by the COVID-19 has since then created one of the most monumental mayhems in the history of education systems. The forced transformation of learning spaces has affected most of the student population, especially in developing and underdeveloped countries. As the COVID-19 continues to cripple most of the education systems of the world, conventional views about education have been challenged. At the heart of the pressured educational changes are the vulnerable groups of learners at risk of stark inequalities.

The United Nations Educational, Scientific, and Cultural Organization (2020), through its Global Education Coalition, targeted to enable equitable and accessible education for learners of all ages amid educational interruptions caused by the COVID-19 crisis. It assisted countries to lessen the negative impacts of the crisis by formulating inclusive educational continuity plans. At the core of this effort to reshape education are the most vulnerable segments such as the students who belong to the group of indigenous peoples. The United Nations (2021) described indigenous peoples as a group of people who practice unique cultures and ways of relating to people and the environment. They have maintained social, economic, and political characteristics that are unique from those of the dominant communities.

In the Philippines, the indigenous peoples account for at least eleven million of the national population. Significant portions are the Lumad groups and the Cordillera groups; other distinct indigenous groups are the Negrito groups, Visayas groups, and Islamized groups (Foundation for the Philippine Environment, 2013). Historically, indigenous peoples have always struggled for human rights problems, and more lately, in the affirmation for an education that is responsive, appropriate, and relevant to them (The Episcopal Commission on Indigenous Peoples, 2014). Towards this end, it is essential 
to gather their distinct views and insights about education. This perennial educational problem, however, has been exacerbated by the present COVID19 crisis.

With the attempt to continue learning amid the menace of the COVID-19 on the higher education system, the Commission on Higher Education, through Republic Act No. 7722, allowed higher education institutions using full online classes to begin as early as June (San Juan, 2020). With this modality of learning, however, the disparity in education has never been more real in the case of the students belonging to the segment of indigenous peoples (Chavez, 2020) because of extant structural problems on electricity and technology access typical in many remote cultural communities (Cahapay, 2020a). Advocacy groups have warned of a "lost generation of learners" if measures are not adopted to address these problems currently encountered (Mateo, 2020).

With the current global COVID-19 crisis and the educational state of disregarded segments, there is a need to understand the totality of the phenomenon by looking into the lived experiences of key people involved. The lived experiences of the students especially from the marginalized group of indigenous peoples is a fertile ground that raises a topic of interest for research. There are educational accounts of the lived experience of students (e.g., Cahapay, 2020b; Fura et al., 2020; Henaku, 2020; Irawan et al., 2020; Rahiem, 2020; Suhail et al., 2020), but the particular educational insights of the students from the marginalized group of indigenous peoples as they live out the present moment has not been written. This paper is different from the mentioned studies above as it extends the educational narrative from the eyes of the students from the marginalized group of indigenous peoples set in a novel situation.

Moreover, phenomenology is adopted as the method of this research. Euber (2020) expressed the need to document the experience during overwhelming periods such as the continuing COVID-19 crisis. One of the emerging research methods that attempts to record experience is phenomenology. It is a method used to describe consciousness from the viewpoint of individuals who have experienced the phenomenon (Smith, 2007). Thus, given the primary reason for putting the locus of experience on the college students belonging to the marginalized group of indigenous peoples who have historically encountered the phenomenon of educational 
inequality, phenomenology is considered as the most suitable method for this study.

This topic that seeks to understand the concept of education from the lens of college students who belong to the indigenous peoples is important for two main reasons. First, it will offer scholars and researchers new knowledge about education as a concept drawn from the lived experience of a marginalized group. As the current crisis is redefining education in all aspects and unimaginable ways, this paper may also provide unique conceptions of education set in a novel context. Furthermore, it will present practical points for education stakeholders. Based on this study, policymakers and authorities may draw practical ways on how they can extend help at the society level to enable vulnerable college students to transition into a more inclusive new normal. It will provide practical insights as well to school administrators and teachers at the school level to formulate contextual measures that will address the current learning crisis and keep these college students in school.

Hence, drawing from the lived experiences of college students from the marginalized group of indigenous peoples, the goal of this paper is to describe the essence of education in the context of the current disruptive COVID-19 crisis.

\section{Methods}

This section presents the methods used in this study. It covers a description of the design, sampling, context, instrument, data collection, and data analysis.

\section{Design}

The study employed the descriptive phenomenological approach called 'reflective lifeworld research' developed by Dahlberg et al. (2008). Its philosophical inspiration is perceived in the goal to describe the complexities of the phenomenon as experienced by the participants. Furthermore, acknowledging a natural position without intentionally mirroring their own experience, researchers in this approach attempt to depict the phenomenon while staying open to the expressed essence of experience (Dahlberg et al., 2008). This approach is suited to this study because it provides a focused and 
objective method in describing the phenomenon of education in the disruptive COVID-19 era from the perspectives of marginalized college students.

\section{Sampling}

The participants of this study were selected using a purposive sampling technique. Robinson (2014) described purposive sampling as an intentional selection of participants based on their ability to explicate a phenomenon, which in this research is the phenomenon of education amid the COVID-19 crisis. Moser (2018) further suggested that, aside from the common experience on the phenomenon, the participants in phenomenology research should differ in some respects to provide for variation. Table 1 displays the characteristics of the participants.

Table 1. Characteristics of the participants

\begin{tabular}{llll} 
Participant & Gender & Age & Tribe \\
\hline A & Female & 21 & Islamized indigenous people \\
B & Male & 23 & Islamized indigenous people \\
C & Male & 20 & Islamized indigenous people \\
D & Female & 22 & Islamized indigenous people \\
E & Female & 20 & Islamized indigenous people \\
F & Male & 20 & Lumad indigenous people \\
G & Male & 20 & Lumad indigenous people \\
H & Female & 19 & Lumad indigenous people \\
I & Female & 20 & Lumad indigenous people \\
J & Female & 21 & Lumad indigenous people \\
\hline
\end{tabular}

According to Thomas and Pollio (2002), a narrower standard for selecting the participants in phenomenology is at least six participants. As much as the researcher wanted to obtain a larger sample size, however, the restrictions caused by the COVID-19 crisis and structural problems such as the internet connection of the target participants did not make it possible. Thus, at the end of the sampling process, there were only 10 qualified participants. This sample does not represent the population but is considered adequate for the purpose of this study. 


\section{Context}

This study was conducted in Mindanao, home to the sizable population of indigenous peoples in the Philippines. Due to constrained access to education, they historically have one of the lowest literacy rates in the country (De Vera, 2007), a perennial issue that has been further aggravated since the emergence of the current global crisis (Chavez, 2020). Thus, this complex circumstance presents an interesting case in point for this study to explore the essence of education amid the disruptive COVID-19 situation as experienced by the college students from the marginalized group of indigenous peoples.

\section{Instrument}

The researcher prepared an interview guide as an instrument of the study. It contained questions that revolved around the phenomenon: the daily world of the participants as college students participating in remote learning during the COVID-19 crisis and its essence. The questions were reviewed by two education professors and a college student to ensure their appropriateness.

\section{Data Collection}

Before the main data collection process, the researcher provided written information about the study. Stressing voluntary and privacy considerations, consent was obtained from the participants. Then, interviews were conducted. Due to the restrictions caused by the current crisis and the structural challenges encountered by the participants, however, the researcher decided for online interviews via Messenger. The questions were presented in the text one by one. The participants wrote their responses. The researcher encouraged the participants to expound on their varied experiences. At the end of the data collection process, the interviews were recorded by the researcher in a master transcript.

\section{Data Analysis}

The analysis in reflective lifeworld research is based upon the "hermeneutic rule" and performed in an alternation between the whole and the parts 
(Dahlberg et al., 2008). This analysis included three major stages. The first stage of data analysis involved the constant review of the transcribed interviews until the researcher was able to divide the text into meaning units related to the phenomenon. The second stage covered the process of organizing the meaning units. A repetitive procedure of grouping and regrouping into meaning clusters was performed until final meaning clusters were generated. The final stage included the organization of the meaning clusters into themes that constituted the phenomenon of interest. These themes were given descriptions.

\section{Result}

Following the three stages of data analysis, the essence of education as experienced by the student was analyzed. Table 2 presents the sample meaning units and the emergent meaning clusters and themes.

Theme 1. It surprised me: Education has a changed ecology. With the continuing restrictions caused by the COVID-19 crisis, education has initially been greatly transformed but much to the disadvantage of the students. The ecology of education has been modified particularly in the learning interactions and modalities, which require more adjustments in the case of college students from the marginalized group of indigenous peoples. The college students recalled these changes in their accounts as follows:

"I can say that learning in this new normal is like a battle against myself due to the major adjustments. We, students, must learn on our own with less guidance from our teachers. Some of our concerns were sometimes unanswered so we just deal with it according to how we understand the lesson" -Participant A.

"I find learning in this distance and remote education far from the kind of instruction in the past which I am used to. It took time to adjust to this new normal. I noticed that the interaction between the teachers and the students is less nowadays than in the face-to-face class. It forces me to learn on my own"-Participant G. 


\section{Table 2.}

\section{The essence of education based on the three stages of data analysis}

Phase I:

Sample Meaning unit

Student is required to learn within the premises of home instead of the school.

Because of the pandemic, the student has to study mainly using gadgets.

Learning is experienced by the student with less interaction with classmates and teachers.

Student is left alone to understand the content with less guidance from the teacher. Lack of gadgets makes attendance of the student to remote classes difficult.

Poor internet connection hinders the student to participate in online class activities.

Family problems related to money make the student worried about continuing to study.

Attention of the student is divided between learning and the need to work to support his studies.

Crisis is only a challenge to study harder towards the realization of personal dreams.

Studying motivates the student to strive harder to improve her family situation in the future.

The mode of studying is a part of the experience towards making a change in the community.

While learning remotely, the student learned skills relevant in the real world.

Learning in crisis taught the student to not give up on any trial in life and just continue. Student believes that a sense of efficacy in learning contributes to success in learning amid hardships.

The lack of resources taught the student to manage time and study harder.

Student learned to own her learning more due to less contact with peers and teachers.
Phase II:

Meaning cluster

Formal education occurs mostly through remote learning.

Independent learning is becoming the new normal in learning.

Structural problems hinder access of the students to education.

Financial issues impede the educational participation of the students.

The result of learning will improve the conditions of the microsystem.

Learning is a process to prepare the students for greater spheres and purposes.

Crisis afforded students with skill on being persistent in difficult situations.
Phase III:

Theme

It surprised me:
Education has a
changed ecology

It overwhelmed me: Education is fraught with divides

It motivated me: Education is a driver of aspiration beyond crisis

It taught me something: Education has unintended positive outcomes

Theme 2. It overwhelmed me: Education is fraught with divides. The COVID-19 crisis has since then revealed existing inequalities in learning 
that make education an even more challenging experience for college students identified to the marginalized group of indigenous peoples. These inequalities can be largely seen in the structural and financial divides that make these college students vulnerable to discontinue learning. Some of the narrations of the college students support this notion of education as a tough experience as follows:

"As a student who lives in a remote village, my main problem is the internet connectivity. There were times when the weather was bad. I walked almost two hours from home going to an area that has a stable internet connection. I did not ride a motorcycle because of rough road and strong current of the river" -Participant J.

"I cannot focus on my class activities because I need to work, I need to support myself. Honestly, I prefer face-to-face learning in school. Why? Because face-to-face learning in school allows me to work in school as well. I can earn money as a student assistant in school, unlike this situation" -Participant L.

Theme 3. It motivated me: Education is a driver of aspiration beyond crisis. The COVID-19 crisis has become an ultimate test to evaluate anew the purpose of education to the college students who belong to the group of indigenous peoples. The participants saw education as an experience towards the achievement of their aspirations beyond the crisis. These aspirations encompass different spheres from personal to the community. These notions are evident in the responses of the college students as follows:

"Despite the stress brought by this mode of learning, I was able to cope up. My difficult experiences coming from a poor family motivate me to continue learning. I have a goal to help my family from poverty through education. If I will be able to finish my college degree, I will have a gainful job in the future and I can help my family" -Participant K.

"This difficult experience of remote learning is only a test for me to become a better teacher in the future. Most people in my community do not realize the value of education and I want to educate them in the future. This is the more challenging task for me. These 
experiences at present will help me become prepared for that task" -Participant B.

\section{Theme 4. It taught me: Education has unintended positive} outcomes. Finally, while the remote education amid the COVID-19 crisis taught disciplinary knowledge, it also resulted in indirect outcomes in the college students who belong to the group of indigenous peoples. These outcomes come in the form of soft skills such as persistence and accountability which college students learned through informal experiences in the process. The college students expressed these unintended outcomes as follows:

"I became more responsible in terms of time management. I have to finish my requirements ahead or on time because I have to work on the other side to financially support myself. I have to budget my time. Despite this difficult experience, it taught me to be a responsible person in the process"-Participant C.

"The semester is about to end and I have survived all the problems that came with remote learning. I realized in this COVID-19 situation not to give up on any trial in life. The one who truly has a dream in life will not give up and just continue to dream until that dream is achieved someday. I learned to be persistent in life" Participant D.

\section{Discussion}

A repetitive process of examining the transcript, data, and themes made the structure of the phenomenon visible to the researcher. The researcher observed a "story" that articulates the structure of the phenomenon. Thus, it would be relevant to purposefully frame the phenomenon in a "story arch" structure. Figure 1 presents this structure of the phenomenon of education in a disruptive COVID-19 crisis. 


\section{EDUCATION}

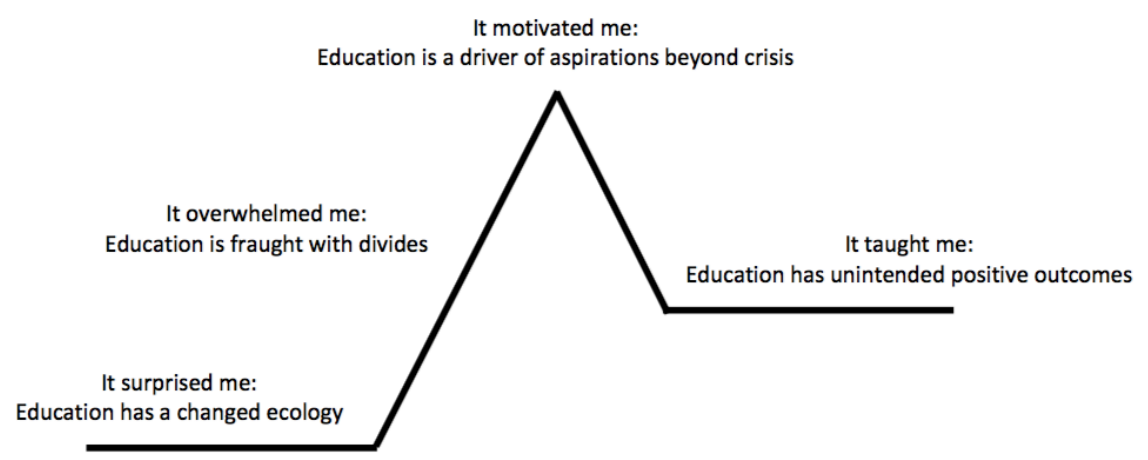

Figure 1. Structure of the phenomenon of education in a disruptive COVID19 crisis

Theme 1 "It surprised me: Education has a changed ecology" is the exposition that appeared common in the descriptive accounts of the college students about their world. Cahapay (2020c) articulated that since the emergence of the current crisis, learning spaces have been transformed from physical spaces to virtual spaces. Di Pietro et al. (2020) also affirmed the change in how the interaction occurs within the changing ecology of education amid the crisis. It can be argued that conventional space and interactions may be emulated in remote education using technologies, but the issue remains when considering the case of the group of indigenous peoples who mostly have extant scarce electricity and technology access. While the impact of the changing ecology in education has affected all students, however, it can be observed that it has been more severe to the college students belonging to the group of indigenous peoples.

Theme 2 "It overwhelmed me: Education is fraught with divides" is the rising action evident in the hurdles and struggles that college students encountered along the way. The perceived divides are already extant before the crisis. Roberts and Hernandez (2019) stated that the level of technology access in the Philippines in terms of connectivity 
often reflects geographical and financial marginalization. They expressed that the group of indigenous peoples in the rural community is one of the segments from which connectivity is often not accessible, or if accessible, it may be costly for most students from indigenous families on a low income. Within the same context, Rotas and Cahapay (2020) reported this problem on digital divides usually intertwined in financial issues. Thus, the current crisis affecting education has distraught most college students belonging to the group of indigenous peoples as divides have been starker now.

Theme 3 "It motivated me: Education is a driver of aspirations beyond crisis" is the turning point when the college students find the determination to survive amid the situation, inspiring them to succeed in the future. This construction of a perspective about education as a tool to achieve aspirations complements the conventional perspective that education is an essential foundation of individuals and communities that brings economic prospects, social opulence, and political constancy (Idris et al., 2012). This perspective has been more strongly held by students amid the COVID-19 crisis as voiced out by the participants in this study. Plan International (2020) also featured the positive testaments of college students impacted by the crisis, underscoring their resilience to keep aspiring despite the difficulties.

Theme 4 "It taught me: Education has unintended positive outcomes" is the resolution in which college students articulate the lessons they covertly learned from the crisis experience. Khamees et al. (2020) noted a similar observation in the field where continued learning experiences in students amid the crisis inculcate their sense of identity and importance. The researchers observed that unintended values are learned by the students when they continue or suspend learning experiences. These instances can be explained in the concept of a hidden curriculum. Dickerson (2007) described a hidden curriculum as a curriculum that operates in school in which something is unintentionally learned through experience other than the stated educational goals. It may include, for example, the values conveyed in the social environment (Kentli, 2009), which in this case is the remote learning environment. 


\section{Conclusion}

This paper aimed to describe the essence of education in the context of the disruptive COVID-19 crisis from the lived experiences of college students who belong to the marginalized group of indigenous peoples. The result uncovered four themes that capture the essence of education: 1.) It surprised me: Education has a changed ecology; 2.) It overwhelmed me: Education is fraught with divides; 3.) It motivated me: Education is a driver of aspiration beyond crisis; 4.) It taught me something: Education has unintended positive outcomes. These themes form the structure of the phenomenon that can be framed in a story arch.

Some practical contributions that may be drawn include the formulation of measures in the society and school levels to address the learning needs of the marginalized college students during a crisis. Appropriate authorities, in synergy with concerned stakeholders, should continue working on providing resilient funded infrastructures for learning to enable technology access in indigenous communities all over the country. On the other hand, school administrators should institutionalize units that will advocate crisis readiness among the students and the instructors should also contextualize the technologies as well as contents used in the instructional implementation.

The unique purpose of this paper, which is to describe the essence of education through the lens of college students belonging to the marginalized group of indigenous peoples, may be one of the strengths of this research. While it may be the first of its kind, however, some limitations must also be noted. The saturation of data may have been maximized if a larger sample size was involved in the research. Owing to the restrictions brought by the crisis, multiple data collection techniques were not also employed as planned in this study. With these limitations, this paper underlines the suggestion to further explore the situation of the most vulnerable students so that enduring solutions may be developed towards a more responsive, appropriate, and relevant education. 
36 Cahapay - Education in COVID-19 Crisis

\section{References}

Cahapay, M. B. (2020a). Philippine Basic Education Learning Continuity Plan: Creating space for Indigenous Peoples toward inclusive postCOVID-19 education. International Journal of Pedagogical Development and Lifelong Learning, 2(1), ep2102. https://doi.org/10.30935/ijpdll/9294

Cahapay, M. B. (2020b). Stranded college students amid COVID-19 pandemic: An existential phenomenology. Journal of Loss and Trauma, 25(6-7), 598-604.

https://doi.org/10.1080/15325024.2020.1770955

Cahapay, M. B. (2020c). A reconceptualization of learning space as schools reopen amid and after COVID-19 pandemic. Asian Journal of Distance Education, 15(1), 269-276.

https://doi.org/10.5281/zenodo.3892969

Chavez, L. (2020, April 03). For Philippines' displaced indigenous students, COVID-19 is one of many threats. Mongabay. Retrieved from https://news.mongabay.com/

Dahlberg K., Dahlberg H., Nyström M. (2008). Reflective lifeworld research. (2nd ed.). Lund: Studentlitteratur

De Vera, D. E. (2007). Indigenous Peoples in the Philippines: A country case study. Presented at the RNIP Regional Assembly Hanoi, Vietnam. Retrieved from http://www.iapad.org/wp- content/uploads/

Di Pietro, G., Biagi, F., Costa, P., Karpiński Z., \& Mazza, J. (2020). The likely impact of COVID-19 on education: Reflections based on the existing literature and international datasets. Luxembourg: Publications Office of the European Union. https://doi.org/10.2760/126686

Dickerson, L. (2007). A postmodern view of the hidden curriculum. Retrieved from http://eaglescholar.georgiasouthern.edu:8080/jspui/bitstream/

Euber, J. (2020, April). Telling the real story of the 2020 pandemic and its effects: It's up to you. New York Times. Retrieved from https://nonprofitquarterly.org/ 
Foundation for the Philippine Environment (2013). Where are Indigenous Peoples Distributed in the Philippines? Retrieved from https://fpe.ph/indigenous-communities.html/view/

Fura, D. L., \& Negash, S. D. (2020). A Study on the Living Experiences of People during the COVID-19 Pandemic: The Case of Wolisso Town Home-Stayed University Students. Journal of Psychological Psychotherapy, 10(384), 2161-0487. https://doi.org/10.35248/21610487.20.10.384

Henaku, E. A., (2020). COVID-19 online learning experience of college students: The case of Ghana. International Journal of Multidisciplinary Sciences and Advanced Technology, 1(2), 54- 62. https://doi.org/10.47577/tssj.v11i1.1511

Idris, F., Hassan, Z., Ya'acob, A., Gill, S. K., \& Awal, N. A. M. (2012). The role of education in shaping youth's national identity. Procedia-Social and Behavioral Sciences, 59, 443-450. https://doi.org/10.1016/J.SBSPRO.2012.09.299

Irawan, A. W., Dwisona, D., \& Lestari, M. (2020). Psychological impacts of students on online learning during the pandemic COVID-19. KONSELI: Jurnal Bimbingan dan Konseling (E-Journal), 7(1), 5360. https://doi.org/10.24042/kons.v7i1.6389

Kentli, D. F. (2009). Comparison of hidden curriculum theories. European Journal of Educational Studies, 1(2), 83-88.

Khamees, D., Brown, C. A., Arribas, M., Murphey, A. C., Haas, M. R., \& House, J. B. (2020). In crisis: medical students in the COVID-19 pandemic. AEM Education and Training, 4(3), 284-290. https://doi.org/10.1002/aet2.10450

Mateo, J. (2020, October 05). As Classes Open, 'Learning Crisis' Highlighted with Millions of Students Left Behind. OneNews. Retrieved from https://www.onenews.ph/

Moser, A., \& Korstjens, I. (2018). Series: Practical guidance to qualitative research. Part 3: Sampling, data collection and analysis. European Journal of General Practice, 24(1), 9-18. https://doi.org/10.1080/13814788.2017.1375091

Plan International (2020). Our dreams must continue, despite the pandemic. Retrieved from: https://plan-international.org/case-studies/ourdreams-must-continue-despite-pandemic 
Rahiem, M. D. (2020). The emergency remote learning experience of university students in Indonesia amidst the COVID-19 crisis. International Journal of Learning, Teaching and Educational Research, 19(6), 1-26. https://doi.org/10.26803/ijlter.19.6.1

Roberts, T., \& Hernandez, K. (2019). Digital access is not binary: The 5'A's of technology access in the Philippines. The Electronic Journal of Information Systems in Developing Countries, 85(4), 1-14. https://doi.org/10.1002/isd2.12084

Robinson, R. S. (2014). Purposive Sampling. In Encyclopedia of Quality of Life and Well-Being Research, 5243-5245. https://doi.org/10.1007/978-94-007-0753-5_2337

Rotas, E. E., \& Cahapay, M. B. (2020). Difficulties in remote learning: Voices of Philippine university students in the wake of COVID-19 crisis. Asian Journal of Distance Education, 15(2), 147-158. https://doi.org/10.5281/zenodo.4299835

San Juan, A. D. (2020, August 15). Colleges, universities not required to delay school opening - CHED. Manila Bulletin. Retrieved from https://mb.com.ph/2020/08/15/

Smith, D. W. (2007). Husserl. New York: Routledge.

Suhail, A., Iqbal, N., \& Smith, J. (2020). Lived experiences of Indian Youth amid COVID-19 crisis: An interpretative phenomenological analysis. International Journal of Social Psychiatry, 002076402096602. https://doi.org/10.1177/0020764020966021

The Episcopal Commission on Indigenous Peoples. (2014). Indigenous peoples education: From alienation to rootedness. In Department of Education (Ed.). Manila: Department of Education Indigenous Peoples Education Office.

Thomas, S.P. \& Pollio, H.R. (2002). Listening to patients: A phenomenological approach to nursing research and practice. New York: Springer Publishing Company, Inc.

United Nations (2021). Indigenous Peoples at the United Nations. Retrieved from https://www.un.org/development/desa/indigenouspeoples/aboutus.html

United Nations Educational, Scientific, and Cultural Organization (2020). COVID-19 education response. Retrieved from https://en.unesco.org/covid19/educationresponse/globalcoalition 
International and Multidisciplinary Journal of Social Sciences, 10(2) 39

World Health Organization. (2021, February 20). WHO Coronavirus Disease (COVID) Dashboard. https://covid19.who.int

Zhou, P., Yang, X. L., Wang, X. G., Hu, B., Zhang, L., Zhang, W., Si, H.-R., Zhu, Y., Li, B., Huang, C.-L., Chen, H.-D., Chen, J., Luo, Y., Guo, H., Jiang, R.-D., Liu, M.-Q., Chen, Y., Shen, X.-R., Wang, X., Zhao, K., \& Shi, Z. L. (2020). Addendum: A pneumonia outbreak associated with a new coronavirus of probable bat origin. Nature, 588(7836), E6-E6. https://doi.org/10.1038/s41586-020-2951-z

Michael B. Cahapay is Assistant Professor IV rank at Mindanato State University-General Santos City, Philippines

Email: mbcahapay@up.edu.ph 